\title{
Naukowe convivium po 40 latach
}

\section{Nie tylko logistyka}

Redaktorzy niniejszej monografii winni są Czytelnikom kilka informacji i wyjaśnień ułatwiających lekturę tej książki. Jest ona owocem międzynarodowej konferencji naukowej z cyklu Veritatis Splendor pt. „Jan Paweł II, który zmienił świat”. Miała ona miejsce w królewsko-papieskim Krakowie w dniu 17 października 2018 roku w auli Collegium Novum Uniwersytetu Jagiellońskiego. Powód był oczywisty: dzień wcześniej minęła czterdziesta rocznica historycznego wydarzenia, jakim był wybór arcybiskupa metropolity krakowskiego Karola kardynała Wojtyły na papieża Kościoła rzymskokatolickiego.

Organizatorami konferencji były trzy podmioty: archidiecezja krakowska wraz z jej obecnym metropolitą, Uniwersytet Papieski Jana Pawła II w Krakowie oraz Instytut Dialogu Międzykulturowego im. Jana Pawła II w Krakowie. Ta ostatnia placówka powstała w 2009 roku jako samorządowa instytucja kultury, powołana przez województwo małopolskie, gminę miejską Kraków oraz Centrum Jana Pawła II „Nie lękajcie się!”. Jej misją ,jest upamiętnianie, upowszechnianie i twórcze rozwijanie dziedzictwa, które pozostawił po sobie Ojciec Święty Jan Paweł II oraz inspirowanie w oparciu o te wartości nowych inicjatyw o wymiarze uniwersalnym, promowanie duchowości, kultury i tradycji związanej z osobą Ojca Świętego Jana Pawła II oraz dialogu między religiami i kulturami, a także działalność naukowa, kulturalna i edukacyjna”.

Statut Instytutu Dialogu Międzykulturowego im. Jana Pawła II w Krakowie, rozdz. 2 , par. 3 . 
O powinnościach dwóch pierwszych organizatorów wobec św. Jana Pawła II nie trzeba wspominać. Są one wszak oczywiste, zarówno dla lokalnego Kościoła, z którego wyszedł, jak i Uniwersytetu zawdzięczającego mu swoje istnienie jako drugiemu założycielowi (po Kazimierzu Wielkim i św. Jadwidze Andegaweńskiej). Dość powiedzieć, że zaciągnięty dług wdzięczności winien być spłacany na różne, ciągle na nowo określane sposoby. Jeśli Jan Paweł II osiem razy pielgrzymował do ziemi krakowskiej i przez swoje gesta et verba (wygłosił tu 19 homilii i 37 przemówień) ${ }^{2}$ pozostawił nam dar, to zgodnie z logiką, której uczył, jest on swoistym zadaniem archidiecezji oraz Uniwersytetu.

Wszystkie te instytucje reprezentowane były przez konkretne osoby, które, jako gospodarze konferencji, zabrały głos na początku i na końcu obrad. W niniejszej monografii wygłoszone referaty znalazły swój zapis w postaci Wstępu (abp prof. Marek Jędraszewski, metropolita krakowski), Przedmowy (prof. Jacek Majchrowski, prezydent m. Krakowa), Pontyfikatu dialogu (mgr Leszek Zegzda, członek ówczesnego Zarządu Województwa Małopolskiego V Kadencji), Podsumowania (ks. prof. Wojciech Zyzak, rektor UPJPII) oraz Słowa na zakończenie (mgr Agata Szuta, dyrektor Instytutu Dialogu Międzykulturowego im. Jana Pawła II).

Kościelną rangę konferencji podkreślała obecność nuncjusza apostolskiego w Polsce, abp. Salvatore Pennacchio, osobiście związanego ze św. Janem Pawłem II poprzez sukcesję apostolską przekazaną mu 6 stycznia 1999 roku podczas sakry biskupiej, który swoją misję dyplomatyczną rozpoczął 3 listopada 2016 roku. Jego wypowiedź zamieszczona została pod znamiennym tytułem, odnoszącym się do głównego tematu konferencji, HABEMUS PAPAM! Czterdziesta rocznica wyboru Jana Pawła II.

Wspomniane wyżej współdziałanie trzech różnych instytucji przywołuje aktualny i ważki problem tworzenia kultury europejskiej i polskiej. Historycznie rzecz biorąc, przeszłość wskazuje na pewien model organizacyjny, w którym właśnie współdziałają instytucje eklezjalne, naukowe i publiczne na szczeblu państwowym i samorządowym. Należy więc z wdzięcznym uznaniem podkreślić fakt, że organizacja tej konferencji przez wymienione wyżej podmioty była aktualizacją tego modelu. Wszak, jak podkreślał zmarły niedawno nestor krakowskich historyków, prof. Jerzy Wyrozumski: „Wartości

\footnotetext{
Por. B. Mielec, Jan Paweł II pielgrzym w ziemi krakowskiej, w: Archidiecezja krakowska na przełomie tysiącleci, red. S. Koperek, S. Szczur, M. Leśniak, B. Mielec, Kraków 2004, s. 159-166.
} 
uniwersalne tworzą się na szczytach nauki, kultury i edukacji” ${ }^{3}$, Kościół zaś „był w chrześcijaństwie zachodnim [...] główną siłą integrującą i unifikującą w zakresie wiary, obyczaju, nauki i kultury, a także instytucji społecznych", a „równocześnie respektował realia życia, dorobek, potrzeby i aspiracje strefowe w sensie etnicznym, a także lokalne" ${ }^{4}$. Chociaż dziś sytuacja kulturowa uległa daleko idącym przemianom, fakt tej współpracy na szczeblu lokalnym należy uznać za oryginalne i potrzebne genius loci królewsko-papieskiego Krakowa. A także pokłosie perspektywicznego i głębokiego zasiewu dokonanego przez jednego z najwybitniejszych krakowian, który apelował: „Nigdy jeden przeciw drugiemu. Jedni przeciw drugim. I nigdy «brzemię» dźwigane przez człowieka samotnie. Bez pomocy drugich. Nie może być walka silniejsza od solidarności" ${ }^{5}$.

\section{Wybór tyłułu i szczegółowej tematyki konferencji}

Chociaż wybór ten był podyktowany faktem historycznej rocznicy, jego znaczenie sięga daleko poza tę konkretną okoliczność. Chodzi w nim bowiem o specyficzną pamięć kulturową, której francuski historyk Jacques Le Goff przypisuje głęboki sens: „Pamięć jest zasadniczym elementem tego, co od niedawna nazywa się tożsamością indywidualną lub zbiorową"6. Zatem jubileusz 40-lecia wyboru Jana Pawła II był okazją do naukowej refleksji nad naszą tożsamością religijno-kulturową, w którą wydarzenie to jest już na trwałe wpisane. Dodajmy, że według biblijnej symboliki liczba „40” oznacza wielką ilość albo długi czas, a zatem wskazuje na pewną perspektywę, z jakiej podejmujemy analizę tego nowego elementu naszego dziedzictwa. Kluczem do niego jest wspomniana pamięć, której eminentny przykład dawał sam Jan Paweł II, gdy podczas pierwszej pielgrzymki do Polski identyfikował się jako człowiek,

\footnotetext{
3 J. Wyrozumski, Chrześcijaństwo a jedność Europy, w: Servo veritatis. Materiały Międzynarodowej Konferencji dla uczczenia 25-lecia pontyfikatu Jego Świątobliwości Jana Pawła II. Uniwersytet Jagielloński 9-11 października 2003 r., red. S. Koperek, S. Szczur, Kraków 2003, s. 59.

$4 \quad$ J. Wyrozumski, Chrześcijaństwo a jedność Europy, w: Servo veritatis..., dz. cyt., s. 56.

Jan Paweł II, Homilia w czasie Mszy św. odprawionej dla świata pracy, Gdańsk 12 czerwca 1987, $\mathrm{nr} 7$.

6 J. Le Goff, Historia i pamięć, tłum. A. Gronowska, J. Stryjczyk, Warszawa 2007, s. 155.

J. F. Drinkard, Liczby, tłum. T. Mieszkowski, w: Encyklopedia biblijna, red. P. J. Achtemeier, tłum. zb., Warszawa 1999, s. 672, kol 2.
} 
„który swoją duchową formację zawdzięcza od początku polskiej kulturze, polskiej literaturze, polskiej muzyce, plastyce, teatrowi - polskiej historii, polskim tradycjom chrześcijańskim, polskim szkołom, polskim uniwersytetom”. A następnie prosił ówczesną polską młodzież: „Pozostańcie wierni temu dziedzictwu! Uczyńcie je podstawą swojego wychowania! Uczyńcie je przedmiotem szlachetnej dumy! Przechowajcie to dziedzictwo! Pomnóżcie to dziedzictwo! Przekażcie je następnym pokoleniom!"’. Można zatem stwierdzić, że rola Jana Pawła II w polskiej i światowej kulturze jako twórcy, uczestnika, obserwatora i duchowego kreatora ${ }^{10}$ domaga się twórczej pamięci, w tym także wieloaspektowych badań naukowych.

Z przebiegu całego pontyfikatu wynika, że polska i chrześcijańska tożsamość papieża pozwoliła mu otworzyć się na doświadczenia innych ludzi, tak osobiste, jak i wspólnotowe. Własna wielowymiarowa tożsamość była źródłem, „z którego Karol Wojtyła czerpał rozumienie dynamiki dziejów, zastosowane później przez niego do zmiany dziejów świata" ${ }^{11}$. Była ona różna od jego poprzedników i następców, lecz może właśnie dlatego „stworzyła najważniejszy pontyfikat od wielu wieków - pontyfikat, którego wpływ będzie odczuwalny zarówno w Kościele, jak i w świecie jeszcze w kolejnych stuleciach" ${ }^{12}$.

Przytoczone wyżej stwierdzenia jednego z najwybitniejszych znawców i komentatorów pontyfikatu Jana Pawła II uzasadniają wybór tytułu konferencji, jak i niniejszej monografii. W nasze dziedzictwo wszedł bowiem „Jan Paweł II, który zmienił świat" i pamięć o nim jest elementem tożsamości Kościoła i narodu. Jednak tytuł ten może wydawać się określeniem zbyt patetycznym i nieadekwatnym $\mathrm{z}$ naukowego punktu widzenia. I to zarówno teologicznego, jak i humanistycznego (historycznego, socjologicznego itp.) Nie bójmy się podjąć tego krytycznego wątku. Wszak naukowy charakter tej monografii zakłada krytyczne myślenie. Podejmijmy zatem próbę zrozumienia wybranego tytułu na trzech płaszczyznach: teologicznej, filozoficznej i naukowej.

\footnotetext{
Jan Paweł II, Przemówienie do młodzieży zgromadzonej na Wzgórzu Lecha, Gniezno 3 czerwca 1979, nr 4.

Jan Paweł II, Przemówienie do młodzieży...., dz. cyt.

Por. Jan Paweł II człowiek kultury, red. K. Flader, W. Kawecki, Kraków 2008.

G. Weigel, Kres i początek. Papież Jan Paweł II - zwycięstwo wolności, ostatnie lata, dziedzictwo, tłum. M. Romanek, Kraków 2012, s. 513.

12 G. Weigel, Kres i początek..., dz. cyt., s. 462.
} 


\subsection{Teologiczny i filozoficzny sens „zmiany świata"}

Z teologicznego punktu widzenia Panem historii jest Bóg i to On zmienia świat. Jednak czyni to także przez ludzi na miarę ich własnego powołania. Jan Paweł II był wybitnym myślicielem i duszpasterzem, „który zmienił świat”, lecz „zmianę” tę należy rozumieć najpierw w znaczeniu teologicznym. Oznacza ona bowiem wejście w misję Jezusa Chrystusa, czyli posługiwanie się środkami, którymi On działał. Hans Urs von Balthasar, którego teologia mocno oddziaływała na Jana Pawła II, trafnie zauważa, że „dla chrześcijańskiego działania, a w dalszym tle dla interpretacji działania Boga w Chrystusie, kryterium nie może stanowić wymierny, zewnętrzny sukces. Podniesienie sukcesu politycznego do rangi głównego celu równałoby się odsunięciu na dalszy plan centrum grawitacji dramatu krzyża i zmartwychwstania oraz zastąpieniu go rzekomo mesjańską, czy wręcz zelocką, działalnością Jezusa. Oznaczałoby to jednak zafałszowanie perspektywy historycznej i nieliczenie się ze świadectwem Biblii. Nie pozostaje więc nic innego, jak poważnie potraktować wezwanie do działania, ale nie dopatrywać się w nim obietnicy sukcesu. W przypowieści zabrania się wyrywania chwastu: «Pozwólcie obojgu róść do żniwa» (Mt 13, 30). Poza tym sterylnie czyste pole pszeniczne nie byłoby pożądane, mogłoby to zaszkodzić pszenicy. Wreszcie w sieci mają zostać złe ryby razem z dobrymi, aż do czasu definitwnego rozdzielenia u kresu czasów”"13. Dlatego w przypadku Jana Pawła II i jego działalności zmieniającej świat mamy do czynienia ze zjawiskiem, które mieści się zarówno na płaszczyźnie empirycznie mierzalnych faktów, jak i fundamentu, który wymyka się naukowemu badaniu. Dzieje się tak zawsze w przypadku postaci, której najgłębszy profil określa jej więź z Absolutem. Warto w tym miejscu przypomnieć trafną uwagę wybitnego francuskiego filozofa, Jeana Guittona, sformułowaną w biografii innej postaci religijnej: „W naszych niejednoznacznych czasach trudniej niż kiedykolwiek wyznaczyć wąską granicę między tym, co przyrodzone, co znajduje się na granicy praw naturalnych, a tym, co nadprzyrodzone. Potrzeba na to wiele czasu. Zanim jednak te trudne procesy się dokonają, należy się posłużyć kryterium zdrowego rozsądku, które lud chrześcijański oraz elity naukowe mogą zastosować od razu na początku i bez wahania. Można przecież osądzić «drzewo po jego owocach»" ${ }^{14}$. Spróbujmy zatem zatrzymać się najpierw przy

${ }_{13}$ H. U. von Balthasar, Teodramatyka 2. Osoby dramatu. Część 1. Człowiek w Bogu, tłum. W. Szymona, Kraków 2006, s. 65.

${ }_{14} \quad$ J. Guitton, Portert Marty Robin, tłum. M. Żurowska, Kraków 2019, s. 30. 
dwóch „owocach” pewnej zmiany, której dokonał Jan Paweł II, czyli modelu jego myślenia i działania.

W prywatnej rozmowie z Jasiem Gawrońskim na temat przyczyn upadku systemu komunistycznego i własnej roli w tym historycznym fakcie Jan Paweł II mówił: „Wydaje mi się, że decydującą rolę odegrało chrześcijaństwo jako takie, jego treść, przesłanie religijne i moralne. Ja po prostu nie przestawałem przypominać, powtarzać, podkreślać, jak ważna jest nie tylko zasada wolności religijnej, ale i wszystkich innych swobód związanych z istotą ludzką" ${ }^{15}$. Papież zatem postrzegał siebie samego jako świadomego chrześcijanina, wyciągającego konkretne, racjonalne wnioski z treści wiary, które następnie były przesłankami do działania w świecie i Kościele. Zasada myślenia stawała się principium agendi $i^{16}$. Doktryna chrześcijańska służy bowiem praktyce duszpasterskiej. W jego optyce nie ma pomiędzy nimi żadnej sprzeczności, jest natomiast konwergencja. $Z$ naukowego punktu widzenia mamy tu do czynienia z tzw. konwergencyjnym myśleniem, które gromadzi fakty i organizuje je w porządku logicznym, we właściwej kolejności ${ }^{17}$. Papież włączał ten psychologiczny model myślenia w swoją refleksję filozoficzną i teologiczną. Wychodził najpierw od fundamentu, jakim jest Objawienie Boże, w świetle którego życie ludzkie jest współbytowaniem i współdziałaniem w wymiarze absolutnym i ostatecznym Boga i człowieka, zaś w doświadczeniu codziennym relacją między ludźmi ${ }^{18}$. W takim więc świetle postrzegał fenomeny, czyli ludzkie sprawy, w tym aktualne problemy. Stosował zatem filozoficzną zasadę przejścia od ,fenomenu do fundamentu. Nie można zatrzymać się na samym doświadczeniu; także wówczas, gdy wyraża ono i ujawnia wewnętrzność człowieka i jego duchowość, refleksja racjonalna winna docierać do poziomu istoty duchowej i do fundamentu, który jest jej podłożem" ${ }^{19}$. Zatem Jan Paweł II myślał metafizycznie i dlatego działał tak, „jakby widział Niewidzial-

15 J. Gawroński, Kolacja z papieżem i inne historie, tłum. M. Woźniak, Kraków 2017, s. 58 .

${ }_{16} \quad$ Warto $\mathrm{w}$ tym miejscu przypomnieć, że wzajemnym stosunkiem teorii i praktyki zajmował się K. Wojtyła już od dawna jako filozof i teolog. Dowodem na to jest np. wykład na Kongresie Filozoficznym w Genui w 1976 r., poświęcony właśnie tej kwestii - K. Wojtyła, Teoria i praxis: temat ogólnoludzki i chrześcijański, w: K. Wojtyła, Osoba i czyn, red. T. Styczeń, W. Chudy, J. W. Gałkowski, A. Rodziński, A. Szostek, Lublin 1994, s. 465-475, czy książka U podstaw odnowy, Kraków 1972.

${ }_{17}$ Por. W. Kopaliński, Słownik wyrazów obcych i zwrotów obcojęzycznych z almanachem, Warszawa 2007, s. 310, kol. 2.

$18 \quad$ Jan Paweł II, Przekroczyć próg nadziei. Jan Paweł II odpowiada na pytania Vittoria Messoriego, Lublin 1994, s. 46.

19 Jan Paweł II, Encyklika Fides et ratio, Watykan 1998, nr 83. 
nego" (Hbr 11, 27), co jest biblijnym określeniem człowieka wierzącego, czyli sprawiedliwego, żyjącego z wiary (por. Hbr 10, 38). Taki modus cognoscendi pozwalał mu dokonywać racjonalnej oceny ludzkich problemów właśnie z punktu widzenia chrześcijańskiej wiary, która zawiera w sobie ogromny potencjał antropologiczno-etyczny. Jest ona bowiem „głęboko antropologiczna, głęboko osadzona we współbytowaniu, we wspólnocie ludu Bożego, oraz we wspólnocie z Tym Przedwiecznym "Ty»" ${ }^{20}$. Warto w tym miejscu przywołać syntetyczne stwierdzenie Georga Weigla, wypracowane na podstawie jego wieloletnich analitycznych badań fenomenu polskiego papieża: „To właśnie umiłowanie prawdziwych, rzeczywistych ludzi oraz pełne pasji zaintereowanie dylematami życia w późnej nowoczesności stanowiło centrum myśli i nauki duszpasterkiej Jana Pawła II, jego mistycyzmu, jego pracy duszpasterskiej, doktryny społecznej, jego podejścia do polityki światowej czy pracy intelektualnej” ${ }^{21}$.

Postrzegana w taki sposób treść chrześcijańskiej wiary, poddana wielorakiej refleksji (filozoficznej, teologicznej, socjologicznej, politologicznej itp.), pozwoliła mu na dokonanie głębokiej oceny ideologii dominujących od Oświecenia aż do dziś, które wypierają z ludzkich sumień chrześcijańską wizję życia osobistego i wspólnotowego. Jego zasługą było klarowne nazwanie i zrozumienie popełnianego przez nie błędu, który określił mianem antropologicznego. Redukuje on człowieka do poziomu części mechanizmu ekonomiczno-społecznego, zapoznając wymiar duchowy, czyli racjonalny, i wolny wybór moralny oraz płynącą z niego odpowiedzialność ${ }^{22}$. Tragicznym skutkiem błędu antropologicznego jest pominięcie fundamentalnego, religijno-moralnego wymiaru rozwoju człowieka i społeczeństwa, czego skutkiem jest erozja praw człowieka oraz ułomne rozumienie globalnej polityki, ekonomii i ekologii $^{23}$. Sformułowana przed laty i przekazywana w prywatnych wypowiedziach Jana Pawła II, a przede wszystkim w Magisterium Kościoła, trafna diagnoza tych ideologii pozostaje nadal aktualna. Co więcej, wobec rozwoju kierowanego w stronę transhumanizmu jeszcze bardziej ujawnia swą przenikliwość i przydatność. Według Jana Pawła II chrześcijaństwo posiada uniwersalną misję ukazywania autentycznego rozwoju jako służby człowiekowi i dobru wspólnemu ludzkości. A czyni to, wychodząc od adekwatnej antropologii, która

\footnotetext{
${ }_{20} \quad$ Jan Paweł II, Przekroczyć próg nadziei..., dz. cyt., s. 46.

${ }_{21}$ G. Weigel, Lekcje nadziei. Moje niespodziewane życie ze świętym Janem Pawłem II, tłum. K. Rybicka, Kraków 2019, s. 160.

${ }_{22}$ Por. Jan Paweł II, Encyklika Centesimus annus, Watykan 1990, nr 13; P. Jaroszyński, Kultura chrześcijańska szansą uniknięcia błędu antropologicznego, w: Błąd antropologiczny, red. A. Maryniarczyk, K. Stępień, Lublin 2003, s. 395-396.

${ }_{23}$ Jan Paweł II, Encyklika Sollicitudo rei socialis, Watykan 1987, nr 33-34.
} 
pozwala na etyczną ocenę stanu dzisiejszej globalnej kultury. Znajduje ona coraz częściej odzwierciedlenie w badaniach naukowych prowadzonych w ramach dyscyplin humanistycznych i społecznych ${ }^{24}$. Zasługą polskiego papieża wydaje się właśnie podkreślenie służebnego charakteru autentycznego rozwoju cywilizacji. W przeciwnym razie aktualne stanie się ostrzeżenie sformułowane przez Carola S. Lewisa, iż „podbój natury przez człowieka, jeśli spełnią się sny niektórych naukowców, oznacza władzę kilkuset ludzi nad niezliczonymi miliardami. [...] Każda [nowa] władza zdobyta przez człowieka jest równocześnie władzą nad człowiekiem”25.

Zatem Jan Paweł II jest autorem oryginalnego i nadal aktualnego modelu teoretyczno-praktycznego o proweniencji chrześcijańskiej, służącego „zmianie świata”. Jak bardzo konkretny i precyzyjny jest ten model, świadczy inna, prywatna wypowiedź Jana Pawła II, sięgająca „krakowskich czasów” jego biskupiej posługi: „Moim współpracownikom lubiłem stawiać dwa pytania. Pierwsze brzmiało: «Jaka prawda wiary rzuca światło na ten problem?». A drugie: «Kogo możemy wziąć albo przygotować do pomocy?». Znalezienie religijnego uzasadnienia dla działania i osoby odpowiedniej do zadań było dobrym początkiem, rokującym nadzieję na powodzenie duszpasterskich przedsięwzięć" ${ }^{26}$. Nie trzeba podkreślać, że pierwszą, odpowiednią osobą, rokującą nadzieje na powodzenie tego przedsięwzięcia, był sam Karol Wojtyła - Jan Paweł II. Warto w tym miejscu przywołać niektóre oceny jego działania, sformułowane przez współpracowników z Kurii rzymskiej, którzy styl działania papieża z Krakowa określali jako: nieagresywna klarowność (kard. Francis Arinze), pełne respektu podejście do światowego episkopatu (kard. William Baum), umiejętność dokonywania ważnych zmian koncepcyjnych przy pomocy ludzi, którzy nie byli ich zwolennikami, np. watykańskiej Ostpolitik (kard. Agostino Casaroli), polityczna skuteczność, możliwa dzięki teologiczno-etycznej wizji polityki (kard. Roger Etchegaray), wewnętrzna osobowa przejrzystość i moc wiary wyzwalającej z lęku (kard. Bernardin Gantin), zdolność prawnego porządkowania rzeczywistości (kard. Zenon Grocholewski), przemyślana i cierpliwie realizowana odnowa Kościoła według wskazań

\footnotetext{
${ }^{24}$ Por. W. Roszkowski, Roztrzaskane lustro. Upadek cywilizacji zachodniej, Kraków 2019; Ch. Delsol, Kamienie węgielne. Na czym nam zależy?, tłum. M. Kowalska, Kraków 2018; Ch. Delsol, Nienawiść do świata. Totalitaryzmy i ponowoczesność, tłum. M. Chojnacki, Warszawa 2017; M. Gierycz, Europejski spór o człowieka. Studium z antroplogii politycznej, Warszawa 2017; G. Kuby, Globalna rewolucja seksualna. Likwidacja wolności w imię wolności, tłum. D. Jankowska, J. Serafin, Kraków 2013.

25 C. S. Lewis, Koniec człowieczeństwa, tłum. M. Sobolewska, Kraków 2013, s. 71-72. 26 Jan Paweł II, Wstańcie, chodźmy!, Kraków 2004, s. 45.
} 
Soboru Watykańskiego II (kard. Jan Schotte) oraz decyzyjność oparta na właściwej hierarchii wartości i poszanowaniu okoliczności (kard. Jozef Tomko) ${ }^{27}$.

Wszystko to pozwala na przybliżenie do teologiczno-filozoficznego sensu owej „zmiany świata”, w którym dostrzegamy oryginalną i głęboką koherencję pomiędzy osobowością Jana Pawła II oraz chrześcijańskim fundamentem jego myślenia i działania, co w języku religijnym określa się mianem świętości.

\subsection{Perspektywa metodologii naukowej}

Jak należy postrzegać tytuł tej monografii w ramach metodologii naukowej? Odpowiedź na to pytanie warto poprzedzić historycznymi uwagami na temat relacji Jana Pawła II ze światem nauki. Ogólnie znane są skomplikowane dzieje relacji nauka - wiara. Wiemy też, w jak znacznej mierze Jan Paweł II przyczynił się zarówno do ich wyjaśniania ${ }^{28}$, jak i ułożenia w nowy sposób. Podejmowane przez polskiego papieża kontakty ze środowiskiem naukowym całego świata zostały udokumentowane $\mathrm{w}$ wielu publikacjach ${ }^{29}$. Kwintescencją poglądów Jana Pawła II na tę kwestię może być fragment $\mathrm{z}$ listu do Georga V. Coyne’a SI napisanego w 1988 roku z okazji 300. rocznicy Philosophiae Naturalis Principia Mathematica Izaaka Newtona: „Zarówno religia, jak i nauka muszą zachować swoją autonomię i zróżnicowanie. Religia nie opiera się na nauce, ani nauka nie jest ekstrapolacją religii. Każda z nich powinna posiadać własne zasady, układ procedur, zróżnicowanie interpretacji i swoje własne wnioski. Chrześcijaństwo posiada źródło swojego usprawiedliwienia w sobie i nie oczekuje od nauki, by stworzyła ona jego fundamentalną apologetykę. Nauka musi zaświadczyć o swej własnej wartości. Tak religia, jak i nauka mogą i powinny podtrzymywać się nawzajem jako różne wymiary kultury ludzkiej, lecz żadna z nich nie może zakładać, że tworzy dla drugiej konieczną przesłankę. Mamy dziś do czynienia z bezprecedensową okazją stworzenia wspólnych wzajemnych relacji pomiędzy nimi, relacji, w których każda dyscyplina

\footnotetext{
${ }_{27}$ Por. G. Weigel, Lekcje nadziei..., dz. cyt., s. 190-216.

28 Por. T. Sierotowicz, Jan Paweł II i sprawa Galileusza - „rehabilitacja” Galileusza?, „Zagadnienia filozoficzne w nauce”, XLV (2009), s. 97-123; por. T. Sierotowicz, Od metodycznej polemiki do polemiki metodologicznej, Tarnów 2008.

29 Np. Rozmowy w Castel Gandolfo, t. 1-2, Warszawa-Kraków 2010.
} 
zachowuje swoją integralność, ale też pozostaje radykalnie otwarta na odkrycia i intuicje drugiej" ${ }^{30}$.

Stwierdzenia te można odnieść także do naukowego badania fenomenu „zmiany świata”, której dokonał papież z Polski podczas swego długiego pontyfikatu. Jak zaznaczyliśmy już wyżej, naukowe badanie tego wielowymiarowego fenomenu jest możliwe przy pomocy właściwych metodologii różnych nauk humanistycznych i społecznych. Jako ludzki fenomen, staje się bowiem uprawnionym tematem badawczym. Dlatego na płaszczyźnie metodologii naukowej nasz temat można potraktować jako realizację otwartego już programu badawczego, w którym stawia się pewną hipotezę. Natomiast „falsyfikacja hipotezy jest wtedy autentyczna, gdy jest zarazem potwierdzeniem hipotezy przeciwnej. Nie warto bowiem porzucać hipotezy, gdy nie mamy na jej miejsce lepszej kandydatki" ${ }^{31}$. Odnosząc to naszego tematu, jego poprawna $\mathrm{z}$ metodologicznego punktu widzenia naukowa falsyfikacja wymagałaby udowodnienia tezy przeciwnej. A mianowicie wykazania, że długi, trwający prawie 27 lat pontyfikat polskiego papieża nie przyczynił się do zmian w świecie i Kościele. Co empirycznie nie jest do udowodnienia i wydaje się przedsięwzięciem karkołomnym. I chociaż takie próby są podejmowane, okazują się jednak uwarunkowane osobistym emocjonalnym podejściem badacza lub założonymi z góry ideologicznymi uprzedzeniami.

Jednak stosując dalej naukową procedurę badawczą, należało przyjąć szczegółowy plan uzasadnienia tak sformułowanego tematu, co było zadaniem autorów zamieszczonych tutaj tekstów. Wyznaczono zatem kilka szczegółowych tematów, w które wprowadzają mniej znane wypowiedzi Jana Pawła II. Dlatego prawie każdy tekst otwiera najpierw cytat, a następnie jego rozwinięcie, określające zadanie autora. Zamieszczone tu artykuły, które pierwotnie zostały wygłoszone jako wykłady podczas wspomnianej konferencji, redaktorzy tej monografii opracowali naukowo, uzupełniając w miarę możliwości i potrzeby, aparat badawczy zaproponowany przez autorów.

Pierwszy tekst syntetyczne przedstawia „Jana Pawła II, który zmienił oblicze świata”. Według kard. dr. Stanisława Dziwisza zasadniczym rysem papieża było podejmowanie odpowiedzialności na miarę powierzanych mu zadań. Autor wybrał sześć obszarów aktywności Jana Pawła II, które uzasad-

\footnotetext{
30 Jan Paweł II, Posłanie Jego Świątobliwości Ojca Świętego Jana Pawł II do Ojca George’a V. Coyne’a dyrektora Obserwatorium Watykańskiego, „Zagadnienia filozoficzne w nauce", XII (1990), s. 7.

${ }_{31}$ A. Grobler, Metodologia nauk, Kraków 2006, s. 127; por. I. Lakatos, Falsyfikacja a metodologia naukowych programów badawczych, w: I. Lakatos, Pisma z filozofii nauk empirycznych, tłum. W. Sady, Warszawa 1995.
} 
niają tezę o jego ogromnej roli w ich przemianie. A mianowicie: świat polityki, świat nauki i kultury, świat młodych, świat pracy, świat cierpienia oraz świat miłosierdzia i świętości.

Drugim tematem badawczym, którym zajął się kard. dr Angelo Bagnasco, jest rola kapłana we współczesnym świecie w świetle adhortacji apostolskiej Jana Pawła II Pastores dabo vobis (Miłość pasterska jako rdzeń tożsamości kapłana i odpowiedź na współczesne wyzwania wedtug Pastores dabo vobis). Autor podkreśla, że źródłem tożsamości księdza jest jego osobista i sakramentalna więź z Chrystusem, dzięki któremu możliwa jest pasterska miłość, realizowana roztropnie w sekularyzującym się świecie.

Carl Anderson w tekście pt. „Nikomu nie godzi się trwać w bezczynności w tym wspanialym i dramatycznym momencie dziejowym" (ChL, nr 3). Aktualna rola świeckich katolików w Kościele i świecie potraktował swój temat zarówno w sposób informacyjny, jak i apelatywny. Z jednej bowiem strony przypomniał cztery obszary aktywności laikatu, wskazane przez Jana Pawła II. Z drugiej podkreślił, że nie zostały one jeszcze podjęte w sposób wystarczający w obliczu potrzebnej reewangelizacji Zachodu.

Z kolei kard. dr Stanisław Ryłko przedstawia globalne duszpasterstwo młodzieży, które podejmował Jan Paweł II. W tekście pt. „Będziecie światłem wśród mroków, jeśli oświeci Was Chrystus" (Bogota, 1986 r.). Światowe Dni Młodzieży jako wkład św. Jana Pawła II w chrześcijańska formację młodych autor prezentuje charyzmat polskiego papieża jako „przyjaciela wymagającego” od młodych. Polegał on na wzajemnym obdarzaniu się człowieczeństwem i był podstawowym środkiem wychowania młodzieży do „miłowania ludzkiej miłości” w sposób wolny i zgodny z sumieniem.

Kard. dr Angelo Scola podjął się analizy porównawczej pontyfikatów Jana Pawła II i papieża Franciszka pod kątem stosunku Kościoła do ubogich. Artykuł pt. „Jeśli pragniesz pokoju, wyjdź naprzeciw ubogim” (Orędzie na Światowy Dzień pokoju 1993 r.). Ciagłość nauczania św. Jana Pawła II i papieża Franciszka o Kościele dla ubogich zawiera zestawienie wypowiedzi i działań obu papieży. Dostrzega ich wspólne źródło w teologicznym pojęciu „preferencyjnej opcji na rzecz ubogich”, które jest stricte chrystologiczne: taki przykład do naśladowania zostawił nam sam Chrystus.

W tę moralną tematykę wpisuje się George Weigel swoim wystąpieniem pt. Relektura eklezjalnego i społecznego znaczenia encykliki Veritatis splendor. Podejmując trud ponownego odczytania tej papieskiej encykliki, nasz autor podkreśla znaczenie Jana Pawła II jako refomatora Kościoła i duchowego przywódcy świata. W pierwszym wymiarze polski papież ukazał właściwe rozumienie teologii moralnej, która podejmuje aktualne problemy człowieka i świata. Od- 
powiada na nie, wskazując na dramatyzm życia moralnego, w którym istnieje konflikt pomiędzy dobrym czynem i czynem złym z natury. Zatarcie tej fundamentalnej różnicy sprawia, że dramat moralny staje się ludzką tragedią. Tymczasem dramatyczny wymiar moralności ma prowadzić do szczęścia, czyli postaw ujętych przez Chrystusa w formie błogosławieństw, dla których normy moralne okazują się poręczami w drodze na szczyt, w czym wspomaga Boża łaska. Z kolei drugi wymiar, społeczne znaczenie encykliki, polega na wskazaniu, iż ludzka wolność jest nierozerwalnie związana z prawdą o dobru. Nie istnieje więc wolność „obojętna na wartości”, gdyż okazuje się ona samowolą niszczącą życie społeczne. Wymaga ona wszak równości ludzi, której nie sposób zagwarantować bez tej samej odpowiedzialności wobec prawa moralnego poznawanego dzięki sumieniu każdego człowieka.

Tematyki moralnej dotyczy również tekst prof. Wojciecha Nowaka pt. „Ewolucja naukowa i techniczna, która chciałaby obejść się bez wartości etycznych, stopniowo zwróci się przeciwko przeznaczeniu samego człowieka" (Orędzie na Światowa Konferencję UNESCO, Meksyk 1982, nr 5). Aktualność papieskiej wizji kultury i nauki wobec zagrożeń transhumanizmu. Autor zastanawia się nad moralną ambiwalencją postępu w medycynie i rewolucji informatycznej, które dokonały się i nadal dokonują się w świecie. Na kanwie ich konkretnych pozytywnych i negatywnych skutków podkreśla wagę autentycznej etyki, którą proponował Jan Paweł II, opierając ją na personalistycznym sensie więzi prawdy i wolności, których wymaga szacunek dla niezbywalnej godności człowieka.

Tekst Dagoberta Valdésa Hernándeza pt. Odnowisz oblicze ziemi: Dziedzictwo nie jest umierająca przeszłościa jest swego rodzaju emocjonalną opowieścią o sytuacji polityczno-społecznej, w której znajduje się jego kraj - Kuba, pozbawiona chrześcijańskiej kultury życia. Autor przedstawia skutki dokonanej w latach 6o. ubiegłego wieku rewolucji, wcielającej w życie ideologię marksizmu-leninizmu, naznaczonej wspomnianym wyżej błędem antropologicznym. Jej skutkiem jest, jak podkreśla autor, destrukcja człowieka i społeczeństwa oraz osłabienie zakorzenionej w katolicyzmie tożsamości narodu kubańskiego. Odpowiedzią na ten stan rzeczy są podejmowane przez chrześcijan-katolików próby przywrócenia godności czlowieka i budowania społeczeństwa obywatelskiego. W tym kontekście autor apeluje o docenienie chrześcijańskiego humanizmu i wywodzącej się z niego kultury życia jako źródła prawdziwego rozwoju, co czynił w wielu miejscach świata, także na Kubie, Jan Pawel II.

Ostatni tekst, autorstwa dr. Krzysztofa Wieliczko OSPPE, jest krótkim sprawozdaniem z działalności Fundacji Jana Pawła II w Rzymie. Autor wskazuje 
w nim na konkretnych przykładach stypendystów Fundacji, iż „dziedzictwo nie oznacza przeszłości”. Misja Fundacji Jana Pawła II jest bowiem praktyczną kontynuacją nauczania wielkiego papieża. Innymi słowy „zmiana świata”, zapoczątkowana przez polskiego papieża, dokonuje się także przez trwającą 28 lat działalność Fundacji, która pomogła w edukacji ok. 1000 osobom $\mathrm{z}$ różnych krajów.

\section{Convivium to coś więcej niż naukowe spotkanie}

Zwykle przyjęło się nazywać naukowe spotkania mianem „konferencji”, oznaczającej zebranie, naradę, rozmowę, lub „sympozjum”, wykorzystując określenie tej części greckiej uczty, która była poświęcona dysputom filozofów na wybrany przez zgromadzonych temat. Tym właśnie była konferencja naukowa z okazji 40-lecia wyboru Jana Pawła II. Proponujemy jednak również inną jej nazwę, a mianowicie łacińskie convivium, które znaczy „uczta”, „biesiada”. W kulturze chrześcijańskiej jest ono używane jako synonim Eucharystii i braterskiego spotkania. Znany jest średniowieczny łaciński tekst modlitwy pt. O Sacrum Convivium, dziś używany jako antyfona do Magnificat w nieszporach liturgicznego oficjum na katolicką uroczystość Bożego Ciała: „O święta uczto, na której pożywamy Chrystusa, odnawiamy pamięć Jego męki, dusze napełniamy łaską i otrzymujemy zadatek przyszłej chwały”. Warto podkreślić, że tekst ten znajduje się w Konstytucji o liturgii Sacrosanctum Concilium Soboru Watykańskiego II, która określa Eucharystię jako „sakrament miłosierdzia, znak jedności, węzeł miłości, ucztę paschalną, podczas której przyjmujemy Chrystusa, duszę napełniamy łaską i otrzymujemy zadatek przyszłej chwały" (KL 47). Zatem sacrum convivium to paschale convivium ac fraternus concursus. Czyli święta uczta, bo paschalna uczta, a dzięki temu braterskie spotkanie.

I tym w swej najgłębszej istocie była naukowa konferencja „w blasku prawdy” o św. Janie Pawle II, „który zmienił świat”. Z tej racji jej zwieńczeniem była Eucharystia odprawiona w krakowskim sanktuarium na „Białych Morzach”. Przy czym kolejność była w tym przypadku odwrócona. Od naukowego, braterskiego concursus przeszliśmy do sacrum paschale convivium. W ten symboliczny sposób zaznaczone zostało przejście od fenomenu osoby Jana Pawła II, analizowanego przez uczestników pontyfikatu i jego dziedzictwa, do fundamentu, którym jest Trójjedyny Bóg. Pierwszy etap konferencji, czyli naukowe convivium, realizował $\mathrm{w}$ wymiarze horyzontalnym jedno $\mathrm{z}$ najważniejszych osią- 
gnięć Karola Wojtyły, a mianowicie jego teorię uczestnictwa. Jest ono właściwością konkretnej osoby, która jest zdolna do działania wspólnie z innymi, a jednocześnie realizuje w ten sposób samą siebie ${ }^{32}$. Autorzy przedstawionych tu tekstów spełniają oba te warunki. Wszystkich, przy oczywistych różnicach biograficznych, łączy właśnie aktywne uczestnictwo w samym pontyfikacie Jana Pawła II lub w dziedzictwie, jakie pozostawił. Co więcej, uczestnictwo to określiło ich własną tożsamość, co można wyczytać w tekstach, które są czymś więcej niż obiektywną prezentacją danego tematu. Zatem ostatnim zadaniem redaktorów niniejszego tomu jest przedstawienie jego autorów.

Kard. Stanisława Dziwisza nie trzeba osobno przedstawiać jako uczestnika pontyfikatu papieża-Polaka. Urodzony w 1939 roku, od 1966 był sekretarzem metropolity krakowskiego, a następnie sekretarzem osobistym Jana Pawła II przez cały jego pontyfikat, a od 1998 drugim prefektem Domu Papieskiego. Wśród wielu pozycji dokumentujących ten okres należy wspomnieć o jego prywatnym kalendarium pontyfikatu, które czeka na naukowe opracowanie jako cenne bezpośrednie źródło historyczne.

Kard. Angelo Bagnasco urodził się w 1943 roku, jest doktorem filozofii, arcybiskupem metropolitą Genui, przewodniczącym Rady Konferencji Episkopatów Europy, autorem kilku książek i artykułów, z których kilka zostało przetłumaczonych na język polski ${ }^{33}$.

Carl Anderson, urodzony w 1951 roku amerykański prawnik, jest trzynastym Najwyższym Rycerzem Zakonu Rycerzy Kolumba, w przeszłości członkiem wielu dykasterii watykańskich, autorem dwóch ksiązek przełożonych na język polski ${ }^{34}$.

Kard. Stanisław Ryłko, urodzony w 1945, jest doktorem nauk spolecznych, obecnie sprawuje funkcję archiprezbitera bazyliki Matki Bożej Większej w Rzymie. Od 1987 roku pracuje w Stolicy Apostolskiej, najpierw jako wieloletni sekretarz, a następnie przewodniczący Papieskiej Rady ds. Świeckich,

\footnotetext{
$32 \quad$ Por. K. Wojtyła, Osoba i czyn..., dz. cyt., s. 311.

${ }_{33}$ A. Bagnasco, Kultura zachodnia w procesie globalizacji, tłum. P. Borkowski, „Społeczeństwo”, R. 18, 4-5 (2008), s. 471-478; A. Bagnasco, Przyszłość Kościoła katolickiego we Włoszech, tłum. P. Borkowski, „Społeczeństwo”, R. 18, 6 (2008), s. 633-642; A. Bagnasco, Przemówienie na otwarcie seminarium „Dobra polityka dla dobra wspólnego": (Todi, 17 października 2011 r.), tłum. P. Borkowski, „Społeczeństwo”, R. 21, 5-6 (2011), s. 157-168; A. Bagnasco, Kwestia antropologiczna w nauce społecznej Kościoła, tłum. P. Borkowski, „Społeczeństwo”, R. 22, 3 (2012), s. 105-115.

${ }_{34}$ A. Bagnasco, Cywilizacja miłości: Co każdy katolik może zrobić, aby zmienić świat, tłum. J. Wocial, Kraków 2009; C. Anderson, J. Granados, Wezwani do miłości. Wprowadzenie do teologii ciała Jana Pawła II, tłum. M. Romanek, Warszawa 2011.
} 
organizator wielu Światowych Dni Młodzieży. Jest autorem wielu publikacji, m.in.: Świeccy w dzisiejszym Kościele. Wyzwania i perspektywy (2000).

Kard. Angelo Scola urodził się w 1941 roku. Ten doktor teologii to emerytowany arcybiskup Mediolanu, w przeszłości wykładowca na uniwersytecie we Fryburgu, a także w Instytucie Badań nad Małżeństwem i Rodziną im. Jana Pawła II przy Papieskim Uniwersytecie Laterańskim w Rzymie. Współpracował z jednym z najwybitniejszych teologów XX wieku - Hansem Ursem von Balthasarem. W 2010 roku otrzymał doktorat honoris causa Katolickiego Uniwersytetu Lubelskiego Jana Pawła II. Autor wielu książek, z których kilka ukazało się w języku polskim ${ }^{35}$.

Prof. George Weigel, urodzony w 1951, to jeden z najwybitniejszych intelektualistów katolickich, pisarz, wykładowca na wielu uczelniach na świecie, także w USA, posiada kilka doktoratów honorowych. Jest uznanym znawcą i komentatorem pontyfikatu Jana Pawła II i autorem jego kilku biografii ${ }^{36}$ oraz wielu artykułów i książek przetłumaczonych na język polski ${ }^{37}$.

Prof. Wojciech Nowak, urodzony w 1949 roku, jest profesorem zw. nauk medycznych, aktualnym rektorem UJ, autorem i współautorem 133 publikacji naukowych, w tym 3 monografii.

Dagoberto Valdés Hernández, urodzony w 1955 roku na Kubie myśliciel i działacz społeczny, z wykształcenia jest inżynierem-agronomem, założy-

35 A. Scola, Osoba ludzka: antropologia teologiczna, tłum. L. Balter, Poznań 2005; A. Scola, G. Reale, Dialog o wartości człowieka, tłum. E. I. Zieliński, Warszawa 2009; A. Scola, Doświadczenie człowieka: u źródeł nauczania Jana Pawła II, tłum. P. Mikulska, Lublin 2010; A. Scola, Warto żyć we wspólnocie: religia, polityka, ekonomia, tłum. M. Masny, Lublin 2015.

${ }_{36}$ G. Weigel, Świadek nadziei. Biografia Jana Pawła II, tlum. M. Tarnowska, J. Piątkowska, D. Chylińska, J. Illg, R. Śmietana, Kraków 2000; G. Weigel, Kres i początek. Papież Jan Paweł II - zwycięstwo wolności, ostatnie lata, dziedzictwo, tłum. M. Romanek, Kraków 2012.

37 G. Weigel, Ostateczna rewolucja: Kościół sprzeciwu a upadek komunizmu, tłum. W. Buechner, Poznań 1995; G. Weigel, Czym jest katolicyzm? 10 kontrowersyjnych pytań, tłum. A. Gomola, Kraków 2003; G. Weigel, Odwaga bycia katolikiem. Kryzys, reforma i przyszłość Kościoła, tłum. J. J. Franczak, Kraków 2004; G. Weigel, Katedra i sześcian. Europa, Stany Zjednoczone i polityka bez Boga, tłum. I. i P. Zarębscy, Warszawa 2005; G. Weigel, Listy do młodego katolika, tłum. J. J. Franczak, Kraków 2006; G. Weigel, Boży wybór. Papież Benedykt XVI i przyszłość Kościoła katolickiego, tłum. D. Chylińska, M. Romanek, R. Śmietana, Kraków 2006; G. Weigel, Wiara rozum i wojna $z$ dżihadyzmem - wezwanie do działania, tłum. K. Jasiński, Warszawa 2009; G. Weigel, Katolicyzm ewangeliczny. Gruntowna reforma Kościoła w XXI wieku, tłum. G. i A. Gomola, Kraków 2014; G. Weigel, Rzymskie pielgrzymowanie, Kraków 2015; G. Weigel, Doświadczanie Boga. Dla wierzacych, poszukujących i wątpiących, tłum. J. J. Franczak, Kraków 2015; G. Weigel, Miasto świętych. Pielgrzymka po Krakowie śladami Jana Pawła II, tłum. M. Kisiel-Małecka, Kraków 2016; G. Weigel, Lekcje nadziei..., dz. cyt. 
cielem pisma „Vitral” (Witraż), obecnie „Convivencia” (Wspólistnienie) oraz Ośrodka Kształcenia Obywatelskiego, którego misją jest krzewienie idei i budowa społeczeństwa obywatelskiego. Jest też organizatorem Kubańskich Spotkań Społeczno-Katolickich. Autor wielu publikacji, m.in.: Felix Varela: Biografia ojca kubańskiej kultury (2006), Kuba: czas podnieść głowy (2009). Jego wykład i obecność na konferencji były związane z pobytem w Polsce z okazji VI Kongresu Kultury Regionów w Nowym Sączu, gdzie wygłosił wykład inauguracyjny.

Dr Krzysztof Wieliczko OSPPE, urodził się w 1961 roku. Od 1987 pracował w USA, gdzie pełnił m.in. funkcję prowincjała w amerykańskiej prowincji zakonu paulinów. Od 2010 roku jest administratorem Fundacji Jana Pawła II w Rzymie, jest droktorem teologii.

Przedstawione tu biografie autorów niniejszej monografii wskazują na to, że Jan Paweł II, „zmieniając świat”, czynił to przez zmianę życia konkretnych ludzi. Swoistym „narzędziem” tej zmiany było i jest jego „promieniowanie ojcostwa". Paradoksalnie zatem to właśnie ta poetycka metafora wydaje się najlepiej oddawać sens tytułu niniejszej monografii, tym bardziej, że jest samookreśleniem osoby, której jest poświęcona.

$\mathrm{Na}$ koniec zatrzymajmy się nad jej interpretacją. Jak wiadomo, Promieniowanie ojcostwa to tytuł dramatu Karola Wojtyły datowanego na rok 1964, a jednocześnie temat XVIII Dnia Papieskiego obchodzonego w Polsce 14 października 2018 roku. Czym ono jest? Odnosząc się z należytym respektem do różnych interpretacji tej metafory autorstwa wielu badaczy literackiej spuścizny Karola Wojtyły, warto przypomnieć jedną, mniej znaną. Wyszła ona spod pióra zmarłego w 2000 roku profesora Papieskiej Akademii Teologicznej, dziś Papieskiego Uniwersytetu Jana Pawła II w Krakowie. Ksiądz profesor Józef Tischner, bo o nim mowa, zaproponował jedną z najbardziej oryginalnych i trafnych interpretacji tej metafory. Jego zdaniem cały poemat jest poświęcony misterium „twórczej wzajemności osób”, które stają się sobą przez innych, obdarzonych zaimkiem „mój, moja, moje”. Można to również nazwać dramatem rodzenia się ludzi, swoistą genealogią osoby ludzkiej. Jednak twórcza wzajemność osób ma swoje źródło w Tym, kto jest „Wzajemnością Najwyższą i Absolutną", czyli w Bogu w Trójcy Jedynym. Dlatego Tischner nazywa „Promieniowanie ojcostwa” arche-dramatem i z uznaniem podkreśla fakt, iż jego autor nie tylko wyraził w sposób poetycki to misterium, ale i zaprosił do uczestnictwa w nim ${ }^{38}$.

${ }_{38}$ Por. J. Tischner, Promieniowanie twórczej wzajemności, w: Twórczość Karola Wojtyty. Materiały z sesji zorganizowanej z okazji 46. Kongersu Eucharystycznego we Wrocławiu, red. Z. W. Solski, Wrocław 1998, s. 43-66. 
W ten sposób doszliśmy do wertykalnego wymiaru naszego tematu, który jednak wymyka się naukowej obiektywizacji: jest ukrytym fundamentem, na którym papież z Polski „zmieniał świat”. Jak sam wyznał: „Chcą zrozumieć mnie z zewnątrz, tyle że mnie da się zrozumieć tylko od wewnątrz" ${ }^{39}$. Wydaje się zatem, iż metafora „promieniowania ojcostwa” będzie nadal kluczem hermeneutycznym jego pontyfikatu. Kluczem nadal aktualnym, co odkryliśmy już dawno w Krakowie. Najbardziej trafny wyraz temu doświadczeniu dał cytowany już ksiądz profesor Józef Tischner, gdy komentował fakt wyboru Jana Pawła II, któy był jednocześnie odejściem z Krakowa: „Tak rządził nami kardynał Karol Wojtyła w archidiecezji karkowskiej. Każdemu wydawało się, że na Jego miejscu dokonałby więcej. Dopiero gdy kardynał odszedł do Rzymu, wydała się Jego sztuka kierowania ludźmi"40. Czy słowa te, zwłaszcza dziś, nie są nadal aktualne?

\footnotetext{
39 G. Weigel, Lekcje nadziei..., dz. cyt., s. 135.

40 Jischner, Z. W. Solski, Misterium ojcostwa, w: Twórczość Karola Wojtyły..., dz. cyt., s. 137 .
} 
Słowa klucze: Kard. Karol Wojtyła, Jan Paweł II, 40 lat wyboru, Kraków, Rzym, teologiczny sens „zmiany świata”, perspektywa metodologii naukowej, convivium

Streszczenie: Konferencja wpisywała się w cykl już wcześniej istniejących spotkań naukowych oraz wręczenia nagrody Veritatis splendor. Zostali zaproszeni świadkowie życia i pontyfikatu Jana Pawła II, zarówno świeccy, jak i duchowni, by właśnie w ten sposób także uczcić 40-lecie wyboru kard. Karola Wojtyły na Stolicę św. Piotra. To naukowe spotkanie nie było tylko historycznym spojrzeniem na wszystkie dokonania papieża Polaka, ale w założeniu było, i takim się też stało, sposobem na wykazanie twórczej perspektywy na przyszłość. Wszystko zasadzało się na teologicznym sensie „zmiany świata” na lepszy. Ukazane zostały więc różne warianty przyszłości dla poszczególnych społeczności wewnątrz Kościoła, a więc: duchownych i świeckich, młodzieży i ludzi starszych oraz ubogich. Przypomniane zarazem zostały wszystkie najważniejsze tezy pontyfikatu Jana Pawła II, które nadal są aktualne.

\section{Scientific convivium after 40 years}

Key terms: Cardinal Karol Wojtyła, John Paul II, $40^{\text {th }}$ anniversary of election, Cracow, Rome, theological meaning of ,the world change”, the prospect of scientific methodology, convivium

Abstract: The conference was part of the cycle of scientific meetings which had been running for some time and it also was associated with conferring the Veritatis splendor award. Amongst the invited guests there were the witnesses of the life and pontificate of John Paul II, both laity and clergy, who wished to celebrate the $40^{\text {th }}$ anniversary of Cardinal Karol Wojtyła's election to the See of St. Peter. This scientific meeting was not only the historic insight into all the achievements of the Pope from Poland, but was also intended, as it turned out successfully, to outline the creative future prospects. The entire conference was based on the theological notion of "changing the world" into better. Therefore the future prospects for various communities inside the Church were presented, i.e. for: clergy and laity, young, older and poor people. By this means, all principal and still relevant theses of John Paul II's pontificate were recollected.

DOI: http://dx.doi.org/10.15633/9788374388306.01 